\title{
Analisis Kemampuan Komunikasi Matematika Siswa Ditinjau dari Gender
}

\author{
Urni Babys $\mathbf{~}^{\bowtie}$
}

Prodi Pendidikan Matematika, STKIP Soe

\begin{tabular}{|c|c|}
\hline Info Artikel & Abstract \\
\hline $\begin{array}{l}\text { Sejarah Artikel: } \\
\text { Diterima } 9 \text { Mei } 2020 \\
\text { Direvisi } 14 \text { Mei } 2020 \\
\text { Disetujui } 19 \text { Mei } 2020 \\
\text { Keywords: Mathematical } \\
\text { communication ability, } \\
\text { gender } \\
\text { Paper type: } \\
\text { Research paper }\end{array}$ & $\begin{array}{l}\text { The purpose of this study is to describe the mathematical communication ability of students in terms } \\
\text { of gender. This type of research is a descriptive study with a quantitative approach. This research } \\
\text { was conducted at Soe Middle School } 32018 / 2019 \text { school year. The source of data in this study were } \\
20 \text { VIII } 10 \text { students, consisting of } 10 \text { men and } 10 \text { women. Sampling using simple random sampling } \\
\text { technique. The data collection technique used is a test of mathematical communication skills. The } \\
\text { research procedure goes through several stages, namely: 1) preparation of mathematics } \\
\text { communication skills test questions, 2) validating test questions and results analysis, 3) providing } \\
\text { tests and collecting test results, 4) analyzing test results, 5) drawing conclusions. From the results, } \\
\text { the communication skills of female students on all indicators have a higher value than male } \\
\text { students. Female students are more thorough, careful and patient in solving mathematical problems } \\
\text { so they are able to communicate mathematical ideas with pictures, diagrams or symbols and have a } \\
\text { better mathematical representation than male students of the study. It can be concluded that the } \\
\text { mathematical communication ability of female students is higher than the mathematical } \\
\text { communication ability of male students that is equal to 58.71\% or a difference of } 17.42 \% \text {. }\end{array}$ \\
\hline
\end{tabular}

\begin{abstract}
Abstrak
Tujuan penelitian ini adalah untuk mendeskripsikan kemampuan komunikasi matematis siswa yang ditinjau dari gender. Jenis penelitian ini adalah penelitian deskriptif dengan pendekatan kuantitatif. Penelitian ini dilakukan di SMP Negeri 3 Soe tahun ajaran 2018/2019. Sumber data dalam penelitian ini adalah siswa kelas VIII ${ }^{10}$ sebanyak 20 orang yang terdiri atas 10 orang laki-laki dan 10 orang perempuan. Pengambilan sampel menggunakan teknik simple random sampling. Teknik pengumpulan data yang digunakan adalah tes kemampuan komunikasi matematika. Prosedur penelitiannya melalui beberapa tahapan yaitu: 1) penyusunan soal tes kemampuan komunikasi matematika, 2) memvalidasi soal tes dan analisis hasil, 3) memberikan tes dan mengumpulkan hasil tes, 4) menganalisis hasil tes, 5) menarik kesimpulan. Dari hasil penelitian diperoleh bahwa kemampuan komunikasi matematika siswa perempuan pada semua indikator memiliki nilai lebih tinggi dari siswa laki-laki. Siswa perempuan lebih teliti, cermat dan sabar dalam menyelesaikan masalah matematika sehingga mampu mengkomunikasikan ide-ide matematika baik dengan gambar, diagram atau simbol dan memiliki representasi matematika yang lebih baik dari siswa lakilaki. Kemampuan komunikasi matematika siswa perempuan lebih tinggi dari kemampuan komunikasi matematika siswa laki-laki yaitu sebesar 58,71 \% atau selisih 17,42\%.
\end{abstract}

(C) 2020 Universitas Muria Kudus

\begin{tabular}{lc}
\hline Alamat korespondensi: & p-ISSN 2615-4196 \\
Program Studi Pendidikan Matematika & e-ISSN 2615-4072 \\
Fakultas Keguruan dan Ilmu Pendidikan Universitas Muria Kudus & \\
Kampus UMK Gondangmanis, Bae Kudus Gd. L. 1t I PO. BOX 53 Kudus & \\
Tlp (0291) 438229 ex.147 Fax. (0291) 437198 & \\
E-mail: urni.babys@gmail.com &
\end{tabular}




\section{PENDAHULUAN}

Kedudukan matematika sebagai salah satu ilmu dasar dalam pembelajaran semakin berkembang pesat dan menuntut banyak inovasi baik dari sisi materi maupun kompetensi yang harus dikuasai siswa setelah mengikuti pembelajaran. Matematika umumnya identik dengan perhitungan angka dan formula, sehingga timbul anggapan bahwa keterampilan komunikasi tidak dapat dibangun pada pembelajaran matematika. Keterampilan komunikasi sangat penting dalam pembelajaran matematika (Rohid, Suryaman dan Rusmawati, 2019).

Kemampuan komunikasi matematika adalah kemampuan menyampaikan gagasan atau ide matematika, baik secara lisan maupun tulisan serta kemampun memahami dan menerima gagasan atau ide matematika orang lain secara cermat, analisis, kritis dan evaluatif untuk mempertajam pemahaman (Lestari dan Yudhanegara, 2017:83). Komunikasi matematika adalah suatu cara siswa untuk menyatakan dan menafsirkan gagasan-gagasan matematika secara lisan maupun tertulis, baik dalam bentuk gambar, tabel, diagram, rumus, ataupun demonstrasi (Prayitno, Suwarsono dan Siswono, 2013). Kemampuan komunikasi matematika itu sendiri mampu memberikan alasan yang rasional dalam memecahkan permasalahan, mampu mengubah bentuk uraian dalam model matematika, serta mampu untuk mengilustrasikan ide atau gagasan matematika dalam bentuk uraian yang relevan (Hendriana dan Kadarisma, 2019). National Council of Teachers of Mathematics (NCTM, 2000) menyatakan bahwa komunikasi sebagai salah satu bagian penting dalam matematika dan pendidikan matematika. Melalui proses komunikasi, siswa dapat saling bertukar informasi, pemahaman dan pengetahuan yang mereka peroleh dalam pembelajaran baik secara lisan maupun tertulis. Komunikasi matematika yang akan dibahas dalam artikel ini adalah komunikasi tertulis.

Komunikasi matematika yang baik diharapkan dapat membantu siswa untuk memiliki pandangan yang lebih luas tentang matematika dan memiliki sikap logis dan cermat dalam menggunakan matematika untuk menyelesaikan masalah sehari-hari. Penelitian Kadarisma (2018) menyatakan bahwa rendahnya kemampuan komunikasi lebih banyak dikarenakan guru kurang menggunakan model pembelajaran yang menuntut siswa aktif berkomunikasi, kebanyakan guru menggunakan model konvensional dalam pembelajarannya. Faktor lain yang juga turut mempengaruhi pandangan dan sikap siswa terhadap matematika itu sendiri adalah faktor gender. Perbedaan jenis kelamin siswa (gender) dapat mengakibatkan perbedaan psikologi belajar siswa. Sehingga siswa laki-laki dan perempuan tentu memiliki banyak perbedaan dalam mempelajari matematika (Nugraha dan Pujiastuti, 2019).

Penelitian Amir (2013) menunjukkan terdapat perbedaan kemampuan matematika siswa dari aspek gender. Perbedaanya tersebut dilihat dari kemampuan menyelesaikan soal spatial. Anak perempuan ditunjukkan memiliki pengalaman spatial diluar sekolah yang lebih rendah daripada anak laki-laki, banyak anak perempuan tidak pernah menggali potensinya untuk berpikir secara spatial kecuali jika berpikir spatial diajarkan dalam kurikulum sekolah. Di sisi lain, siswa perempuan lebih unggul dalam kemampuan komunikasi (verbal) matematis, lebih termotivasi, terorganisasi dalam belajar. Hasil penelitian (Dilla, Hidayat dan Rohaeti, 2018) menunjukkan tingkat kepercayaan 95\% terdapat hubungan positif faktor gender dan resiliensi matematis siswa terhadap pencapaian kemampuan berpikir kreatif matematis siswa SMA. Artinya terdapat hubungan positif antara perbedaan gender dan resiliensi dalam pencapaian kemampuan berpikir kreatif matematis siswa yaitu sebesar $86,6 \%$. Hal ini berarti perbedaan gender dan resiliensi memiliki pengaruh atau kontribusi sebesar $86,6 \%$ terhadap kemampuan berpikir kreatif matematis siswa.

Hasil observasi di SMP Negeri 3 Soe menunjukkan bahwa siswa laki-laki lebih cenderung santai dan lebih suka bermain daripada belajar, kurang tekun dan cepat bosan. Sebaliknya siswa perempuan lebih tertarik belajar dan berdiskusi selama proses pembeajaran.

Dalam menyelesaikan soal-soal matematika siswa perempuan lebih teliti dan menuliskan dengan lebih tepat. Siswa laki-laki lebih suka menjawab secara lisan dan malas untuk menulis dengan lebih terperinci.

Pentingnya komunikasi matematika dan perbedaan gender yang turut mempengaruhi komunikasi matematika menyebabkan perlunya kajian mendalam tentang bagaimana kemampuan komunikasi metamatika siswa ditinjau dari gender. Dengan demikian tujuan yang ingin dicapai dalam penelitian ini adalah untuk mendeskripsikan kemampuan komunikasi matematika siswa yang ditinjau dari gender.

\section{METODE PENELITIAN}

Jenis peneltian yang digunakan dalam penelitian ini adalah deskriptif dengan pendekatan 
kuantitatif. Penelitian ini dilaksanakan di SMP Negeri 3 Soe tahun ajaran 2018/2019. Sumber data dalam penelitian ini adalah siswa kelas VIII ${ }^{10}$ sebanyak 20 orang yang terdiri atas 10 orang lakilaki dan 10 orang perempuan. Pengambilan sampel menggunakan teknik simple random sampling. Teknik pengumpulan data yang digunakan adalah tes kemampuan komunikasi matematika.

Indikator komunikasi matematika yang digunakan dalam penelitian ini merujuk dari Lestari dan Yudhanegara (2017:83) disederhanakan menjadi; (1) menghubungkan benda nyata, gambar dan diagram, ke dalam ide matematika; (2) menjelaskan ide, situasi dan relasi matematika, secara lisan dan tulisan dengan benda nyata, grafik dan aljabar; (3) kemampuan memahami, menginterpretasikan dan mengevaluasi ide-ide matematika; (4) kemampuan dalam menggunakan istilah-istilah, simbol-simbol matematika, dan struktur-struktur untuk menyajikan ide-ide, menggambarkan hubunganhubungan dan pembuatan model; (5) menyatakan peristiwa sehari-hari dalam bahasa atau simbol matematika.

Prosedur penelitiannya melalui beberapa tahapan yaitu : 1) penyusunan soal tes kemampuan komunikasi matematika, 2) memvalidasi soal tes dan analisis hasil, 3) memberikan tes dan mengumpulkan hasil tes, 4) menganalisis hasil tes, 5) menarik kesimpulan. Instrument berupa soal tes yang disusun dalam bentuk soal uraian sebanyak 5 nomor pada materi Teorema Phytagoras. Setiap nomor soal mewakili satu indikator kemampuan komunikasi matematika.

Data hasil pekerjaan siswa dianalisis menurut gender, dengan menggunakan statistik deskriptif dicari nilai rata-rata dan persentase tiap indikator dan ditafsisirkan untuk kemudian dideskripsikan.

\section{HASIL DAN PEMBAHASAN}

Penelitian yang dilakukan kepada 20 orang siswa diantaranya 10 orang siswa laki-laki dan 10 orang siswa perempuan untuk mengukur kemampuan komunikasi matematika siswa ditinjau dari gender diperoleh data yang ditampilkan dalam Tabel 1.

Hasil analisis data pada Tabel 1 terlihat bahwa kemampuan komunikasi matematika siswa laki-laki dan perempuan berbeda-beda. Untuk indikator menghubungkan benda nyata, gambar dan diagram, ke dalam ide matematika, siswa perempuan mendapat nilai 5\% lebih tinggi dari siswa laki-laki. Dari hasil pekerjaan siswa terlihat bahwa kebanyakan siswa laki-laki kesulitan dalam memahami gambar sehingga tidak mampu menghubungkan gambar ke dalam ide matematika menyebabkan pekerjaan siswa laki-laki tidak sampai pada hasil akhir atau salah. Hal ini didukung oleh hasil penelitian Pratiwi (2015) yang menyatakan bahwa siswa laki-laki yang terbiasa menyelesaikan soal dengan cara yang sudah ditetapkan menyatakan langkah pemecahan masalah dengan cara coba-coba, merespon secara lisan namun sulit dipahami dan kurang teliti dalam menyesuaikan hasil dengan gambar.

Indikator yang terkait dengan menjelaskan ide, situasi dan relasi matematika, secara lisan dan tulisan dengan benda nyata, grafik dan aljabar, terlihat bahwa siswa perempuan mendapat nilai $4,48 \%$ lebih tinggi dari laki-laki.

Tabel 1. Nilai Komponen Komunikasi Matematika Siswa Perempuan dan Laki-laki

\begin{tabular}{|c|c|c|c|c|c|}
\hline No & $\begin{array}{c}\text { Indikator Kemampuan Komunikasi } \\
\text { Matematika } \\
\end{array}$ & $\begin{array}{c}\text { Rata-rata Nilai } \\
\text { Perempuan } \\
\end{array}$ & $\begin{array}{c}\% \text { Nilai } \\
\text { Perempuan }\end{array}$ & $\begin{array}{c}\text { Rata-rata Nilai } \\
\text { Laki-laki } \\
\end{array}$ & $\begin{array}{l}\text { \% Nilai Laki- } \\
\text { laki }\end{array}$ \\
\hline 1. & $\begin{array}{l}\text { Menghubungkan benda nyata, gambar dan } \\
\text { diagram, ke dalam ide matematika }\end{array}$ & 84 & 52,5 & 76 & 47,5 \\
\hline 2. & $\begin{array}{l}\text { Menjelaskan ide, situasi dan relasi } \\
\text { matematika, secara lisan dan tulisan } \\
\text { dengan benda nyata, grafik dan aljabar }\end{array}$ & 70 & 52,24 & 64 & 47,76 \\
\hline 3. & $\begin{array}{l}\text { Kemampuan memahami, } \\
\text { menginterpretasikan dan mengevaluasi ide- } \\
\text { ide matematika }\end{array}$ & 86 & 57,72 & 63 & 42,28 \\
\hline 4. & $\begin{array}{l}\text { Kemampuan dalam menggunakan istilah- } \\
\text { istilah, simbol-simbol matematika, dan } \\
\text { struktur-struktur untuk menyajikan ide-ide, } \\
\text { menggambarkan hubungan-hubungan dan } \\
\text { pembuatan model }\end{array}$ & 61 & 67,03 & 30 & 32,97 \\
\hline 5. & $\begin{array}{l}\text { Menyatakan peristiwa sehari-hari dalam } \\
\text { bahasa atau simbol matematika }\end{array}$ & 57 & 64,04 & 32 & 35,96 \\
\hline & Total & 71,6 & 58,71 & 53 & 41,29 \\
\hline
\end{tabular}


Hasil ini sebenarnya tidak terlalu jauh berbeda antara laki-laki maupun perempuan karena baik laki-laki maupun perempuan kurang mampu menjelaskan ide secara tertulis. Dari hasil pekerjaan siswa menunjukkan bahwa siswa lakilaki maupun perempuan belum mampu menuliskan dengan benar dan lengkap langkahlangkah penyelesaian soal, tidak menuliskan rumus, tidak menyelesaikan soal dengan tepat dan tidak menarik kesimpulan sehingga kemampuan menjelaskan ide matematis dalam tulisan masih kurang.

Hal ini sejalan dengan hasil penelitian Dilla, Hidayat dan Rohaeti (2018) menyimpulkan bahwa siswa dengan resiliensi matematis yang kurang cenderung mengerjakan apa adanya, bahkan tidak selesai sampai proses hasil akhir penyelesaian soal karena adanya perasaan takut salah dan kurangnya ketertarikan menjawab soal baik gender laki-laki maupun perempuan.

Hasil analisis untuk indikator ke-tiga yaitukemampuan memahami, menginterpretasikan dan mengevaluasi ide-ide matematika, diperoleh hasil yaitu nilai siswa perempuan juga lebih tinggi dari siswa laki-laki dengan selisih $15,44 \%$. Siswa laki-laki kurang dalam menuliskan dan mengevaluasi kembali hasil pekerjaan yang telah ditulis, lebih suka menulis langsung pada hasil akhir, tidak teliti mengakibatkan masih terdapat banyak kekurangan dalam hasil akhir yang kemudian mengurangi perolehan nilai yang maksimal. Analisis indikator 4 dan 5 terkait kemampuan dalam menggunakan istilah-istilah, simbol-simbol matematika, dan struktur-struktur untuk menyajikan ide-ide, menggambarkan hubungan-hubungan dan pembuatan model dan menyatakan peristiwa sehari-hari dalam bahasa atau simbol matematika rata-rata nilai siswa dan laki-laki cukup rendah dibanding 3 indikator sebelumnya. Indikator ke-empat selisih nilainya $34,06 \%$ sedangkan indikator 5 selisih nilainya $28,08 \%$. Pada indikator ini siswa perempuan cenderung untuk menyelesaikan soal dengan caranya sendiri tetapi menjawab sampai hasil akhir. Sedangkan siswa laki-laki lebih mahir dalam menggambarkan ide matematis dengan simbol, namun tidak menuliskan jawaban sampai akhir sehingga jawaban akhirnya lebih cenderung salah atau bahkan tidak dituliskan. Hasil penelitian Nugraha dan Pujiastuti (2019) memperoleh hasil yang menujukkan kesamaan diantaranya untuk siswa perempuan, komponen indikator menyelesaikan lebih tinggi nilainya dari pada menyatakan suatu situasi atau ide matematis dalam bentuk simbol atau model matematis. Ini terlihat dari hasil jawaban siswa perempuan yang cenderung lebih mengutamakan menyelesaikan melalui caranya sendiri dengan mengabaikan komponen dalam menyatakan suatu situasi atau ide matematis dalam bentuk simbol atau model matematis. Sebaliknya untuk siswa laki-laki lebih tinggi dalam indikator menyatakan suatu situasi atau ide matematis dalam bentuk simbol atau model matematis dari pada menyelesaikannya, terlihat dari hasil jawaban siswa yang lebih mengutamakan komponen dalam menyatakan suatu situasi atau ide matematis dalam bentuk simbol atau model matematis tetapi kurang tepat dalam menyelesaikannya. Ini berarti, siswa perempuan lebih menguasai dalam penyelesaiannya, sedangkan siswa laki-laki lebih menguasai dalam indikator menyatakan suatu situasi atau ide matematis dalam bentuk gambar.

Secara keseluruhan, kemampuan komunikasi matematika siswa perempuan lebih tinggi dari siswa laki-laki dimana total nilai ratarata siswa perempuan adalah 71,6 atau $58,71 \%$ sedangkan total nilai rata-rata siswa laki-laki adalah 53 atau 41,29\%. Penelitian Amir (2013) menunjukkan bahwa anak laki-laki memiliki kemampuan yang tinggi dalam hal matematika, namun perempuan lebih unggul dalam aspek efektifnya (tekun, teliti, cermat). Di sisi lain, siswa perempuan lebih unggul dalam kemampuan komunikasi (verbal) matematis, lebih termotivasi, terorganisasi dalam belajar.

Kemampuan komunikasi matematika siswa akan menjadi lebih baik selain karena faktor gender, juga ditentukan oleh kegiatan pembelajaran di kelas. Kemampuan komunikasi matematika bisa dibentuk oleh guru dengan membiasakan siswa mengemukakan pendapat baik secara lisan atau tulisan, menciptakan pembelajaran yang menarik dengan melibatkan siswa dan memberi kesempatan siswa untuk bereksplorasi. Pembelajaran yang menarik dapat diciptakan dengan menerapkan metode mengajar yang inovatif, tidak monoton dan terpaku pada guru.

Penelitian Ula, Murtono dan Ulya (2018) menyimpulkan bahwa: 1) terdapat perbedaan ratarata kemampuan komunikasi matematis pada kelas yang mendapat perlakuan model pembelajaran TPS dengan kelas yang mendapat perlakuan model pembelajaran ekspositori, 2) kemampuan komunikasi matematik siswa yang menerima pembelajaran model TPS dapat mencapai kualifikasi keefektifan yang ditentukan. Hasil yang sama juga dikemukakan oleh Kadarisma (2018) bahwa peningkatan kemampuan komunikasi matematik yang pembelajarannya menggunakan Open-Ended lebih baik daripada 
yang menggunkan pendekatan konvensional. Perbedaan gender bukan hanya berakibat pada perbedaan kemampuan dalam matematika, tetapi juga cara memperoleh pengetahuan matematika. Banyak pendapat yang mengatakan bahwa perempuan tidak cukup berhasil mempelajari matematika dibandingkan dengan laki-laki. Selain itu perempuan hampir tidak pernah mempunyai ketertarikan yang menyeluruh pada soal-soal teoritis seperti laki-laki. Perempuan lebih tertarik pada hal-hal yang praktis dari pada yang teoritis. Namun di lain pihak, tidak sedikit siswa perempuan yang memiliki keberhasilan dalam kemampuan matematika (Amir, 2013). Oleh karena itu kesetaraan gender dan penerapan metode pembelajaran yang tepat akan membuat siswa memiliki kemampuan matematika yang baik terutama kemampuan komunikasi matematika yang membawa siswa pada penguasaan kompetensi yang menunjang kecakapan hidupnya. Pola pembelajaran yang tepat dapat meningkatkan minat, motivasi dan membentuk kepercayaan diri siswa yang secara tidak langsung meningkatkan kemampuan komunikasi matematika siswa. Sejalan dengan hasil penelitian Hendriana dan Kadarisma (2019) bahwa kemampuan komunikasi matematis dipengaruhi oleh self-efficacy. Serta self-efficacy berpengaruh positif terhadap kemampuan komunikasi siswa, artinya semakin tinggi self-efficacy siswa, maka akan semakin tinggi pula kemampuan komunikasi siswa.

\section{SIMPULAN}

Simpulan dari penelitian ini adalah kemampuan komunikasi matematika siswa perempuan lebih tinggi dari kemampuan komunikasi matematika siswa laki-laki sebesar $58,71 \%$ atau selisih sebesar $17,42 \%$. Kemampuan komunikasi matematika siswa perempuan pada semua indikator memiliki nilai lebih tinggi dari siswa laki-laki. Siswa perempuan lebih teliti, cermat dan sabar dalam menyelesaikan masalah matematika sehingga mampu mengkomunikasikan ide-ide matematika baik dengan gambar, diagram atau simbol dan memiliki representasi matematika yang lebih baik dari siswa laki-laki. Berdasarkan hasil penelitian ini disarankan kepada guru agar mengupayakan peningkatan kemampuan komunikasi matematika dengan memperhatikan gender dan penggunaan metode pembelajaran yang meningkatkan minat dan motivasi belajar siswa laki-laki dan perempuan.
DAFTAR PUSTAKA

Amir, Z. 2013. Perspektif Gender dalam Pembelajaran Matematika. Jurnal UIN Sultan Syarif Kasim Riau, 12.

Dilla, S. C., Hidayat, W. dan Rohaeti, E. E. 2018. Faktor Gender dan Resiliensi dalam Pencapaian Kemampuan Berpikir Kreatif Siswa SMA. Journal of Medives, 2 (1): 129-136.

Henderiana, Heris dan Kadarisma, Gida. 2019. Self-Efficacy dan Kemampuan Komunikasi Matematis Siswa SMP. JNPM (Jurnal Nasional Pendidikan Matematika), 3(1): 153-164.

Kadarisma, Gida. 2018. Penerapan Pendekatan Open-Ended dalam Meningkatkan Kemampuan Komunikasi Siswa SMP. Anargya: Jurnal Ilmiah Pendidikan Matematika, 1(2): 77-81.

Lestari, K. E. dan Yudhanegara, M. R. 2017. Penelitian Pendidikan Matematika. Bandung: PT Refika Aditama.

Nugraha, T. H dan Pujiastuti, H. 2019. Analisis Kemampuan Komunikasi Matematis Siswa Berdasarkan Perbedaan Gender. Edumatica, 09(01): 1-7.

Pratiwi, D. D. 2015. Analisis Kemampuan Komunikasi Matematis dalam Pemecahan Masalah Matematika Sesuai dengan Gaya Kognitif dan Gender. Al-Jabar: Jurnal Pendidikan Matematika, 6 (2): 131 - 141.

Prayitno, S., Suwarsono dan Siswono, T. Y. 2013. Identifikasi Indikator Kemampuan Komunikasi Matematis Siswa dalam Menyelesaikan Soal Matematika Berjenjang pada Tiap-Tiap Jenjangnya. Konferensi Nasional Pendidikan Matematika V. Malang: Universitas Negeri Malang.

Rohid, N., Suryaman dan Rusmawati, R. D. 2019. Students' Mathematical Communication Skill (MCS) in Solving Mathematics Problems. Anatolian Journal of Education, 4 (2): 19-30.

The National Council Of Teacher Of Mathematics (NCTM). 2000. Principles and Standards For School Of Mathematics. USA: Library of Congress Cataloguing in Publication.

Ula, I. D., Murtono dan Ulya, H. 2018. Efektivitas Model Pembelajaran Think-Pair-Share (TPS) Terhadap Kemampuan Komunikasi Matematis Siswa. Anargya: Jurnal Ilmiah Pendidikan Matematika, 1 (1): 51-58. 